EVERYDAY NURSING ETHICS 
Other titles by Kath Melia

Nursing Ethics (with I. E. Thompson and K. M. Boyd)

Learning and Working: the occupational socialization of nurses 


\section{EVERYDAY NURSING ETHICS}

\section{KATH M. MELIA}

B.Nurs. (Manc.), Ph.D.

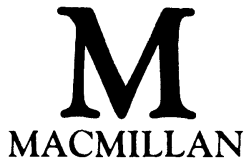


All rights reserved. No reproduction, copy or transmission of this publication may be made without written permission.

No paragraph of this publication may be reproduced, copied or transmitted save with written permission or in accordance with the provisions of the Copyright, Designs and Patents Act 1988, or under the terms of any licence permitting limited copying issued by the Copyright Licensing Agency, 33-4 Alfred Place, London WC1E 7DP.

Any person who does any unauthorised act in relation to this publication may be liable to criminal prosecution and civil claims for damages.

First published 1989

Reprinted 1991

\author{
Published by \\ MACMILLAN EDUCATION LTD \\ Houndmills, Basingstoke, Hampshire RG21 2XS \\ and London \\ Companies and representatives \\ throughout the world \\ Typeset by Wessex Typesetters \\ (Division of The Eastern Press Ltd) \\ Frome, Somerset \\ British Library Cataloguing in Publication Data \\ Melia, Kath M. \\ Everyday nursing ethics. \\ 1. Medicine, Nursing. Ethical aspects \\ I. Title \\ $174 ' .2$
}

ISBN 978-0-333-47152-4 ISBN 978-1-349-10399-7 (eBook)

DOI 10.1007/978-1-349-10399-7 


\section{CONTENTS}

Preface

vii

Introduction

1 To lie or not to lie?

2 Measuring freedom

3 Cruel to be kind?

4 Whose morals are they anyway?

22

5 Balance of power 28

6 Whose side are you on?

7 Justice for all

8 The search for objectivity

9 An easy death?

10 Acts of faith

59

11 To tell or not to tell

65

12 Ethics in context

72

Further reading

81

Index

83 


\section{ACKNOWLEDGEMENTS}

The author and publisher wish to thank Nursing Times for permission to reproduce articles which appeared originally in the journal within the Series 'Everyday Ethics for Nurses'. 


\section{PREFACE}

As a practical introduction to nursing ethics Everyday Nursing Ethics is for both nursing students and qualified nurses. It takes a case-based approach to a range of issues which confront all nurses and challenges them to think about the ethical dimension of their work. Nurses working in daily clinical contact with patients should be able to identify with at least some of the cases and so be able to use the book within their practice rather than viewing ethics as some kind of ivory tower philosophical discussion which does not relate to practice. Nursing students will find the book a stimulating resource which sets theory firmly into practical settings.

Each chapter deals with an important issue. In a brief and readable way it introduces the relevant ethical theory which is then developed so that the reader can build up an understanding of the different arguments that have been put forward by key moral philosophers in order to justify particular moral stances. These arguments are illustrated by relating them directly to a case so that the reader can see how ethical debate works. The cases quoted are, for the most part, not the dramatic ethical dilemmas; rather they are about the everyday realities which nurses face when ethical decisions are being taken or have been taken. So the book is not about 'do we turn off the machine?' but more about 'what are the implications for nurses in a personal and professional sense when the machine is turned off?'

It is important to realise that the book is not about deciding what is right and wrong in nursing practice. Each of us is entitled to a position and so no one should be excluded from voicing an opinion this is the essence of true ethical debate. However, discussion is likely to be more constructive if we have a clear idea about how to 
put arguments together, and an insight into the reasoning behind the moral positions we take.

The book is designed for use by individual nurses or as a basis for ward or classroom-based group discussion. Each chapter includes points for discussion; an annotated bibliography at the end of the book will enable readers to take the issues further. 